\title{
Nutritive value of improved populations Brachiaria ruziziensis
}

\section{Valor nutritivo de populações melhoradas de Brachiaria ruziziensis}

\author{
Luciana Linhares Marcelino ${ }^{1 *}$; Gisele Rodrigues Moreira²; Fausto Souza \\ Sobrinho $^{3}$; Maria Izabel Vieira de Almeida ${ }^{4}$; Antônio Carlos Cóser ${ }^{5}$; Gláucio de \\ Mello Cunha ${ }^{6}$; Flávio Rodrigo Gandolfi Benites ${ }^{7}$
}

\begin{abstract}
A low number of Brachiaria ruziziensis (Syn. Urochloa) cultivars available on the market and a lack of information about its forage potential have made it difficult to expand its cultivated area, and have therefore made it necessary to implement a breeding program for this species. Thus, the objective of this work was to evaluate the nutritional value of ten improved populations of Brachiaria ruziziensis (Syn. Urochloa) and two controls (B. ruziziensis cv. Kennedy and B. brizantha cv. Marandu). The experimental design was a randomized block design with three replications in five sections. The data were submitted to analysis of variance in the subdivided plot in which the primary factors were the populations and the secondary cuts. The Tukey test was used at $5 \%$ of significance for the comparison of means. The genotypes used came from the third recurrent selection cycle of Embrapa dairy cattle, originating from the interbreeding of clones which had been identified as superior. The height of the cuts was $10 \mathrm{~cm}$ in relation to the ground. The material was cut and weighed in the field to obtain the sample weights to determine the nutritional forage value. After drying, the samples were ground in $1 \mathrm{~mm}$ sieves for chemical analyzes and in vitro digestibility. The best CP, ADF and NDF levels observed in IV populations (lower levels of ADF and NDF at 93 days of cut interval and lower NDF contents at 35 and 41 days of cut interval), population VI (higher CP content in the interval of 93 days, lower DM content at 64 and 93 days of cut interval, and lower NDF content at 35 and 64 days of cut interval) showed that these populations can be evaluated under grazing even at an advanced maturation stage. The objective of these selections was to evaluate the nutritional value of improved populations of Brachiaria ruziziensis (Syn. Urochloa) in order to obtain more homogeneous populations for implantation of grazing experiments.
\end{abstract}

Key words: Animal nutrition. Forage. Vegetable breeding.

\footnotetext{
${ }^{1}$ M.e, Ciências Veterinárias, Centro de Ciências Agrárias, Alegre, Universidade Federal do Espírito Santo, UFES, ES, Brasil. E-mail: 1lmzootecnista@yahoo.com

2 Prof $^{a}$ Dr $^{\mathrm{a}}$, Centro de Ciências Agrárias e Engenharias, Departamento de Engenharia Rural, UFES, Alegre, ES, Brasil. E-mail:giselerm@yahoo.com.br

3 Dr. Pesquisador, Empresa Brasileira de Pesquisa Agropecuária, EMBRAPA Gado de Leite, Juiz de Fora, MG, Brasil. E-mail:fausto. souza@embrapa.br

${ }^{4}$ Prof $^{\mathrm{a}} \mathrm{Dr}^{\mathrm{a}}$, UFES, Alegre, ES, Brasil. E-mail: maria.i.almeida@ufes.br

5 Dr. Pesquisador Aposentado, EMBRAPA Gado de Leite, Prof. Visitante Nacional Sênior, PVNS, CCA/UFES, Alegre, ES, Brasil. E-mail:acoser1@yahoo.com.br

6 Prof. Dr., Centro de Ciências Agrárias e Engenharias, UFES, Alegre, ES, Brasil. E-mail:glaucioml@yahoo.com.br

7 Pós-Doc, Pesquisador, EMBRAPA Gado de Leite, Juiz de Fora, Brasil. E-mail:flavio.benites@embrapa.br

* Author for correspondence
} 


\section{Resumo}

O reduzido número de cultivares de Brachiaria ruziziensis (Syn. Urochloa) disponíveis no mercado, a ausência de informações sobre seu potencial forrageiro que vem dificultando a expansão de sua área cultivada tornaram necessário a implantação de um programa de melhoramento genético desta espécie. O objetivo do trabalho foi avaliar o valor nutricional de dez populações melhoradas e duas testemunhas (B. ruziziensis cv. Kennedy e B. brizantha cv. Marandu). O delineamento experimental utilizado foi o de blocos ao acaso com três repetições, em cinco cortes. Os dados foram submetidos à análise de variância conjunta no esquema de parcela subdividida no qual o fator primário foram as populações e o secundário os cortes. Para a comparação das médias utilizou-se o teste de Tukey a 5\% de significância. Os genótipos utilizados foram provenientes do terceiro ciclo de seleção recorrente na Embrapa Gado de Leite, originadas do intercruzamento de clones identificados como superiores. A altura dos cortes foi de $10 \mathrm{~cm}$ em relação ao solo. O material foi cortado e pesado em campo para obtenção dos pesos das amostras para realização das avaliações do valor nutritivo da forragem. Após a secagem, procedeu-se a moagem das amostras em peneira de $1 \mathrm{~mm}$ para realização das análises químicas e digestibilidade in vitro. Os melhores teores de PB, FDA e FDN observados nas populações IV (menores teores de FDA e FDN aos 93 dias de intervalo de corte e menores teores de FDN aos 35 e 41 dias de intervalo), população VI (maior teor de PB no intervalo de corte de 93 dias, menor teor de FDA aos 64 e 93 dias de intervalo de corte e menor teor de FDN aos 35 e 64 dias de intervalo de corte) demonstram que mesmo em avançado estágio de maturação essas populações podem ser avaliadas sob pastejo. O objetivo dessas seleções foi avaliar o valor nutricional de populações melhoradas de Brachiaria ruziziensis (Syn. Urochloa) visando obter populações mais homogêneas para implantação de experimentos de avaliações sob pastejo.

Palavras-chave: Forragem. Melhoramento vegetal. Nutrição animal.

\section{Introduction}

Brachiaria ruziziensis (Syn. Urochloa) presents positive attributes such as high forage quality and nutritive value, response to fertilization, high acceptability (M. E. R Santos et al., 2011), fast establishment with high growth at the beginning of the rainy season, can be used in a consortium with legumes, has concentrated flowering and high seed production (Valle, Macedo, Euclides, Jank, \& Resende, 2013).

The small number of Brachiaria ruziziensis (Syn. Urochloa) cultivars available on the market and a lack of information on its forage potential have made it difficult to expand its cultivated area, and have therefore made it necessary to implement a breeding program for this species (Souza, Lédo, Koop, Pereira, \& Souza, 2009).

The interest in a recurrent selection program is to obtain genetic gains for characteristics of agronomic interest at each new selection cycle (Hallauer, Carena, \& Miranda 2010), which expresses the progress of the working population in relation to the performed selection.

The objective of these selections was to evaluate the nutritional value of improved Brachiaria ruziziensis (Syn. Urochloa) populations aiming to obtain more homogeneous populations for implanting grazing experiments.

\section{Material and Methods}

The experiment was carried out in the Atlantic Forest Biome (Experimental Field of the Embrapa Dairy Cattle in the Municipality of Coronel Pacheco-MG) located in the Zona Mata region of Minas Gerais at $414 \mathrm{~m}$ altitude, $21^{\circ} 35^{\prime} 08^{\prime \prime} \mathrm{S}$ and $43^{\circ} 15^{\prime} 04^{\prime \prime} \mathrm{W}$.

The climate of the area is CWA mesothermal according to the Köppen classification, defined as having a temperate rainy season in summer and dry winter between June and September. The average annual rainfall is $1600 \mathrm{~mm}$, while the 
average annual temperature is $22.5^{\circ} \mathrm{C}$. (Figures 1 and 2) illustrates the annual mean precipitation and temperature during the experimental period. The soil of the experimental area showed the following characteristics according to Table 1 .

The experiment was carried out by seedlings in tubes being propagated by seeds and taken directly to the experimental area. The best plants were selected and cloned to obtain the seedlings for field evaluations.
The experimental design was complete randomized blocks with 12 treatments and three replicates. The treatments consisted of the 10 improved populations of B. ruziziensis (Syn. Urochloa) and the two controls (B. ruziziensis cv. Kennedy and B. brizantha cv. Marandu). The experimental plots were $24 \mathrm{~m}^{2}$, composed of six lines of four meters in length and spaced one meter apart.

Table 1

Results of soil analysis in the experimental area of Coronel Pacheco-MG

\begin{tabular}{cccc}
\hline Characteristics & \multicolumn{3}{c}{ Characteristics } \\
\hline Sand $\left(\mathrm{dag} / \mathrm{kg}^{-1}\right)$ & 48 & $\mathrm{H}+\mathrm{Al} \mathrm{cmol}(\mathrm{c}) \mathrm{dm}^{-3}$ & 4.13 \\
Silt $\left(\mathrm{dag} / \mathrm{kg}^{-1}\right)$ & 15 & Sum of bases cmol $(\mathrm{c}) \mathrm{dm}^{-3}$ & 1.99 \\
Clay $\left(\mathrm{dag} / \mathrm{kg}^{-1}\right)$ & 37 & Effective CEC cmol $(\mathrm{c}) \mathrm{dm}^{-3}$ & 1.99 \\
$\mathrm{Ca}^{2+} \mathrm{cmol}(\mathrm{c}) \mathrm{dm}^{-3}$ & 1.1 & total CEC cmol $(\mathrm{c}) \mathrm{dm}^{-3}$ & 6.12 \\
$\mathrm{Mg}^{2+} \mathrm{cmol}(\mathrm{c}) \mathrm{dm}^{-3}$ & 0.6 & $\mathrm{M} \%$ & 0 \\
$\mathrm{Al}^{3+} \mathrm{cmol}(\mathrm{c}) \mathrm{dm}^{-3}$ & 0.0 & $\mathrm{~V} \%$ & 33 \\
$\mathrm{~K}$ & 112 & $\mathrm{pH} \mathrm{mols} \mathrm{de} \mathrm{H}$ & 5.1 \\
\hline $\mathrm{P} \mathrm{mg} / \mathrm{dm}^{3}$ & 3.1 & O.M.dag $/ \mathrm{Kg}$ & 2.86 \\
\hline
\end{tabular}

The soil was prepared in a conventional system with plowing, harrowing and correction of fertility levels. The seedlings were manually planted in the field in October 2013 in a plantation of three plants/ $\mathrm{m}^{2}$, spaced $1 \mathrm{~m}$ between rows. First, $100 \mathrm{~kg} / \mathrm{ha}$ of $\mathrm{P}_{2} \mathrm{O}_{5}$ were used in the planting fertilization. The fertilization maintenance was performed according to the recommendation of (P. M. Santos, Primavesi, \& Bernardi, 2010) using $350 \mathrm{~kg} / \mathrm{ha}$ of the $08-28-16$ (NPK) formula. The total cover fertilization dose was divided into five plots and always performed when the soil presented good humidity. The plots were kept free of invasive plants by cutting the grass and weeding.

Five cuts were made after a uniformity cut in the year 2014. The height of the cuts was $10 \mathrm{~cm}$ in relation to the soil. The whole plant cuts were determined by their development, which were evaluated in the field and in greenhouse.

The material was cut and weighed in the field to obtain the sample weights to determine the nutritional forage value. After drying, the samples were ground in $1 \mathrm{~mm}$ sieves for chemical analyzes and in vitro digestibility. Chemical analyzes were performed at the Laboratory of Food Analysis of Embrapa Dairy Cattle. The following variables were evaluated: crude protein (CP - $\%)$, in vitro dry matter digestibility (IVDMD -\%), acid detergent fiber (ADF - \%), neutral detergent fiber (NDF), lignin (LIG -\%) and ashes (ASH -\%). In vitro dry matter digestibility was determined using the method proposed by Tilley and Terry (1963), which occurs in two stages: the first, in which the samples are incubated individually in tubes containing 
ruminal inoculum and buffer solution; and the second in which the residue obtained after 48 hours of incubation is subjected to acidic digestion with pepsin (Tilley \& Terry, 1963). Measurements were performed on near infrared spectrophotometer equipment (NIRS).

The joint analysis of variance of the five cuts was performed in a split-plot scheme, with the primary factor being the cuts and the secondary factor the populations, as well as the Tukey test to compare the factor means. These statistical procedures were performed using the (SAS program).

\section{Results and Discussion}

In the joint analysis of variance, significance was detected for the effect of population $\mathrm{x}$ cut interaction for the CP, ADF and NDF levels. Significant differences between the improved populations were detected for the ADF and NDF levels, and between the cuts for all variables. Thus, it is possible to detect differences in the of IVDMD, LIG and ASH contents between the performed cuts, independently of the analyzed improved populations. However, the selection of populations for CP, ADF and NDF contents depends on the time at which the cut was performed (Table 2).

Table 2

Summary of the joint variance analyzes for six variables of nutritional value evaluated in ten populations of Brachiaria ruziziensis and two controls in five cuts in the municipality of Coronel Pacheco, Minas Gerais

\begin{tabular}{ccccccc}
\hline \multirow{2}{*}{ Variation source } & \multicolumn{7}{c}{ Mean squared } \\
\cline { 2 - 7 } & CP\% & IVDMD\% & ADF\% & NDF\% & LIG\% & ASH\% \\
\hline Block & 12.30 & 31.00 & 10.86 & 12.67 & 0.19 & 2.01 \\
\hline Population & 3.95 & 5.79 & $21.11^{*}$ & $25.33^{*}$ & 0.28 & 3.52 \\
\hline Error (a) & 1.97 & 2.49 & 3.92 & 4.96 & 0.13 & 1.72 \\
\hline Cut & $142.38^{*}$ & $120.77^{*}$ & $779.04^{*}$ & $143.55^{*}$ & $39.72^{*}$ & $39.05^{*}$ \\
\hline Pop. x Cut & $1.22^{*}$ & 4.29 & $5.06^{*}$ & $3.54^{*}$ & 0.17 & 0.92 \\
\hline Error (b) & 3.47 & 1.68 & 3.67 & 3.80 & 0.23 & 3.12 \\
\hline Error (c) & 0.75 & 3.01 & 2.83 & 2.32 & 0.12 & 0.92 \\
\hline CV\% (a) & 9.86 & 2.30 & 6.24 & 3.54 & 12.55 & 12.07 \\
\hline CV\% (b) & 13.08 & 1.89 & 6.04 & 3.10 & 16.70 & 16.23 \\
\hline CV\% (c) & 6.06 & 2.52 & 5.30 & 2.42 & 11.88 & 8.83 \\
\hline
\end{tabular}

* Significant at $5 \%$ significance by the F-test. $\mathrm{CP}=$ Crude protein; $\mathrm{IVDMD}=\mathrm{In}$ vitro dry matter digestibility; $\mathrm{ADF}=$ acid detergent fiber; $\mathrm{NDF}=$ Neutral detergent fiber; $\mathrm{LIG}=$ Lignin; $\mathrm{ASH}=$ Ashes; $\mathrm{CV} \%=$ Coefficient of variation.

The estimates of the CVs\% obtained in this work generally ranged from $1.89-1.70 \%$, which evidences the good accuracy of the evaluations and gives high reliability to the obtained results. These values were similar to those found in works with other forage species such as Panicum (Lédo et al., 2008), elephant grass (Shimoya, Pereira, Ferreira, Cruz, \& Carneiro, 2002) and alfafa (Ferreira, Botrel, Pereira, \& Cruz 1999; Souza et al., 2004).
In the cut performed on $07 / 09 / 14$ with a 64 -day interval, the ash content $12.53 \%$ was higher than in the other cuts, except for the cut performed on 01/14/14 with a 41-day interval. Although minerals do not provide energy to animals, unsatisfactory amounts in forages in any of the 17 elements considered essential for animals may limit the digestion, absorption and use of dietary components (Norton, 1982). Flores et al. (2013) mentioned 
reduced ash levels as a function of the increase in the physiological age of the plant (Table 3).

The in vitro dry matter digestibility levels were similar in the cuts performed on $09 / 07 / 14$ with a $64-$ day interval and in the cut performed on $02 / 19 / 14$ with an interval of 35 days, and higher than the cut done on 10/08/14 with an interval of 93 days. In evaluating the IVDMD levels of Coastcross, Tifton 68 and Tifton 85, Cedeno, Rocha, Pinto, Muniz and Gomide (2003) found IVDMD values of $60.69 \%$,
$65.77 \%$ and $60.53 \%$, respectively, at the 42 -day cut interval, and values of $47 \%, 30 \%, 55.49 \%$, $57.41 \%$ at 70 days of cut interval, respectively, for the same forages, demonstrating that the evaluated populations showed good quality with digestibility levels above 55\% (Leng, 1990). The lower IVDMD content at the 93-day cut interval is due to changes in the chemical composition of forages with advancing physiological age of the plants (Carvalho \& Pires, 2008).

Table 3

Means in the cut intervals for in vitro digestibility of dry matter (IVDMD), lignin (LIG) and ashes (ASH) performed ten populations of Brachiaria ruziziensis and two controls were carried out in the municipality of Coronel Pacheco, MG

\begin{tabular}{cccc}
\hline CUTS & IVDMD $\%$ & LIG $\%$ & ASH $\%$ \\
\hline 1st cut 01/04/14 (41 days) & $65.97 \mathrm{bc}$ & $4.47 \mathrm{a}$ & $11.09 \mathrm{ab}$ \\
\hline 2nd cut 02/19/14 (35 days) & $70.20 \mathrm{a}$ & $1.87 \mathrm{~cd}$ & $10.54 \mathrm{~b}$ \\
\hline 3rd cut 05/05/14 (74 days) & $68.91 \mathrm{ab}$ & $3.24 \mathrm{~b}$ & $10.55 \mathrm{~b}$ \\
\hline 4th cut 07/09/14 (64 days) & $70.58 \mathrm{a}$ & $2.71 \mathrm{bc}$ & $12.53 \mathrm{a}$ \\
\hline 5th cut 10/08/14 (93 days) & $68.29 \mathrm{~b}$ & $2.05 \mathrm{~cd}$ & $9.72 \mathrm{~b}$ \\
\hline
\end{tabular}

* Means followed by the same letter in the column do not differ by Tukey test at $5 \%$ probability.

The highest lignin content was found in the cut performed on 01/14/14 with a 41-day interval, while the lowest lignin content was found in the cut performed on $05 / 05 / 14$ with a 74 -day interval. Water availability, temperature and radiation are factors which affect the bromatological composition and the energy availability of forage, and a lower light intensity reduces the productivity of tropical grasses and the production of cell wall components such as lignin (Leonel et al., 2009a, 2009b). The highest lignin content found in the cut interval of 41 days is due to the high temperature of the cut period. However, the lower lignin content in the cut performed on $05 / 05 / 14$ with a 64-day interval is due to the reduced growth of the plants which occurred in the low temperature and low water availability period (GRAPH 2).

The Kennedy cultivar had the highest $\mathrm{CP}$ content in the cuts made on $01 / 14 / 14$ with an interval of
41 days, and 05/05/14 with an interval of 74 days, but the highest CP content of $14.80 \%$ was found in the cut on $10 / 08 / 14$ in the population VI. No differences were observed in CP contents between the populations and cultivars evaluated in the cuts performed on 02/19/14 and 07/19/14 with intervals of 35 and 64 days, respectively. The cuts performed at the 74 and 93-day intervals resulted in higher $\mathrm{CP}$ contents (Table 4). Crude protein contents below $7 \%$ are limiting to animal production due to lower voluntary consumption, reduced digestibility and negative nitrogen balance (Minson, 1990). The studied populations in this work met the minimum requirements of crude protein required by ruminants in all cut intervals. Light intensity and water availability are the environmental factors which most affect plant growth. However, changes in light intensity are fundamental in the development and production processes (Atroch, Soares, Alvarenga, \& 
Castro, 2001). The increase in temperature which occurred in the cut interval of 93 days may explain the higher CP content obtained by population VI (Figure 2).

With the exception of the 74-day interval, the Kennedy cultivar had the lowest content of ADF, with similar content to populations $\mathrm{V}$ and IX in the 35-day cut interval, populations III to $\mathrm{X}$ in the cut performed with an interval of 64 days, and populations IV and VI in the cut performed in the 93-day interval. The cuts performed at the 35, 64 and 93 day intervals resulted in lower ADF levels (Table 5). These levels were below $40 \%$ and did not lead to a reduction in consumption and could be classified as highly digestible (Nussio, Manzano, \& Pedreira, 1998). In an experiment with Brachiaria brizantha cv. MG-5, (Costa et al., 2007) observed ADF levels of $36.00 \%$ with a cut interval of 60 days. The harvesting time of the forage, either by cutting or grazing, should be associated with the height or age of the plant and forage harvested with an advanced physiological age has low digestibility and nutritive value (Costa et al., 2007). Changes in temperature and radiation cause changes in the physiology and metabolism of plants, causing lower lignification of the cell wall, decreased metabolic activity of cells and less conversion of photosynthetic products to components of the cell wall (Michael et al., 2008). Lower radiation and temperature was registered during the experimental period and there was also low water availability in the cut performed with an interval of 64 days, which may explain the higher ADF content. There was an increase in solar radiation and temperature in the cutting period with a 93-day interval, which may explain the lower ADF content in relation to the other cuts (Figures 1 and 2).

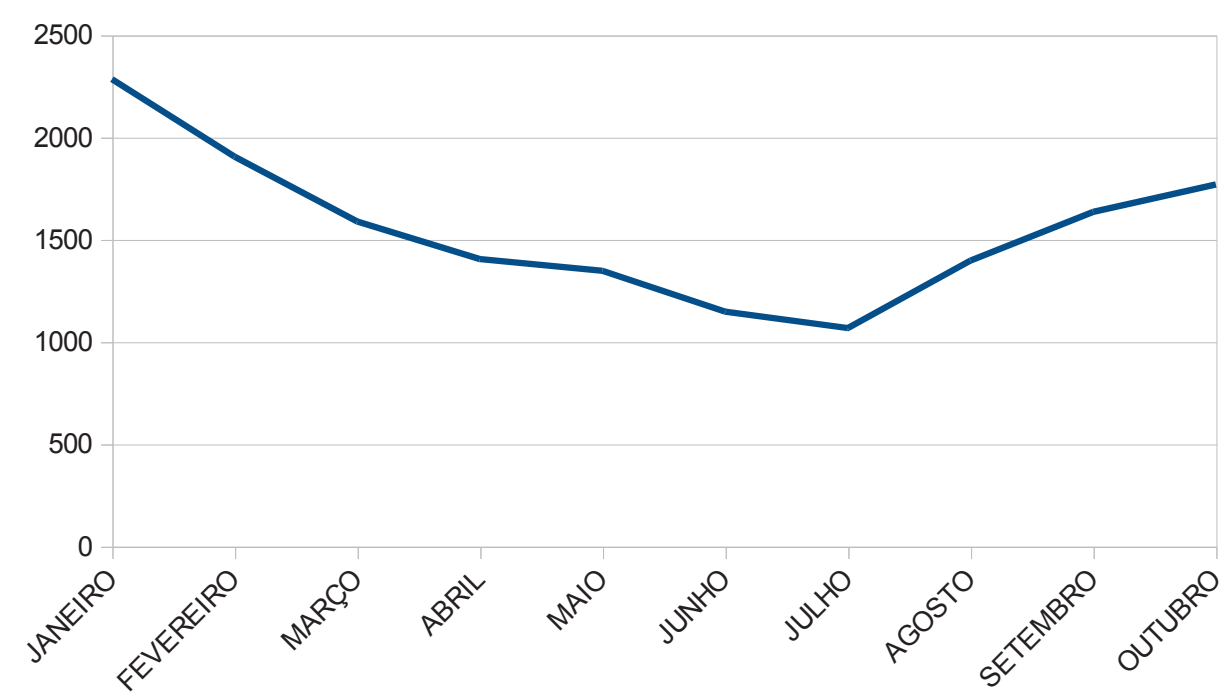

Figure 1. Solar radiation (KJm2) registered from January to October 2014. Source: Instituto Nacional de Meteorologia - Inmet Estação Meteorológica Automática de Coronel Pacheco/MG Latitude: $-21546728^{\circ}$ Longitude: $-43.261029^{\circ}$. 


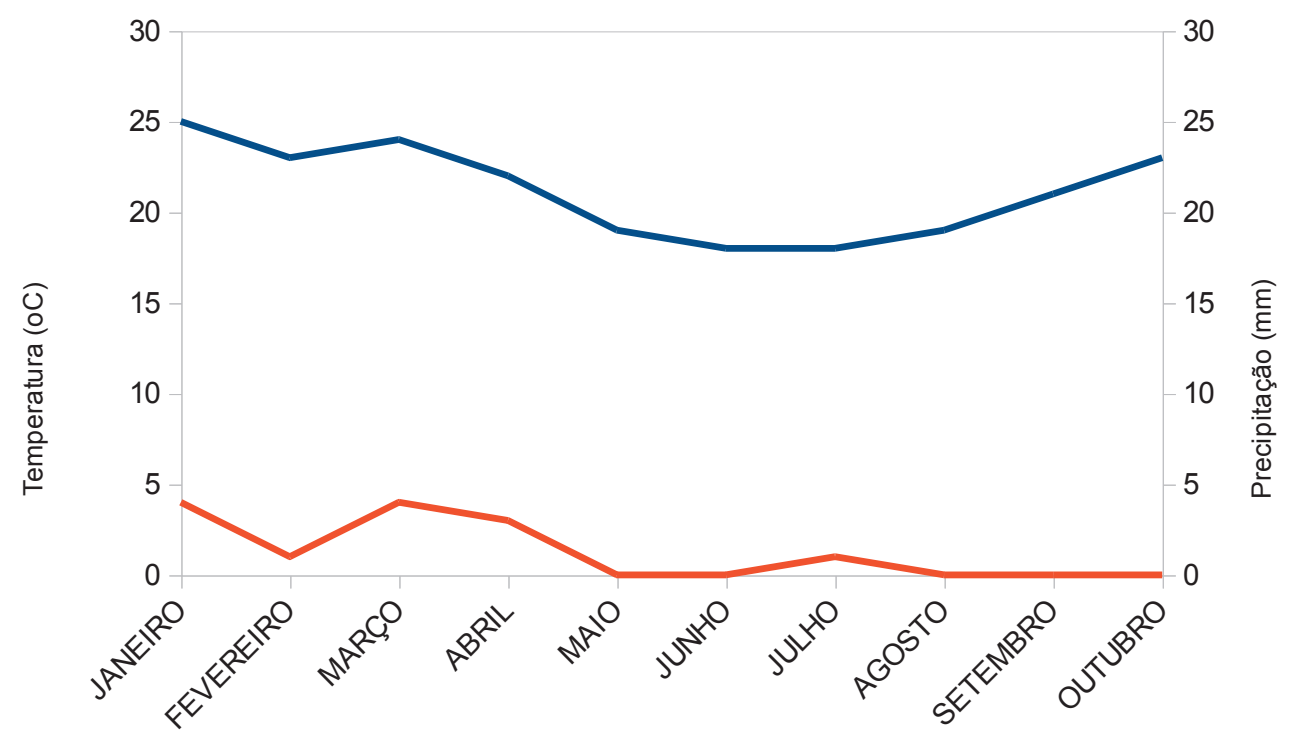

Figure 2. Temperature $\left({ }^{\circ} \mathrm{C}\right)$ and precipitation $(\mathrm{mm})$ recorded from January to October 2014. Source: Instituto Nacional de Meteorologia - Inmet Estação Meteorológica Automática de Coronel Pacheco/MG, Latitude: $-21.546728^{\circ}$ Longitude: $-43.261029^{\circ}$.

Table 4

Means of crude protein $(\mathrm{CP} \%)$ in percentage obtained in the improved populations and controls in five cuts in the municipality of Coronel Pacheco, MG

\begin{tabular}{|c|c|c|c|c|c|}
\hline \multirow[b]{2}{*}{ Pop. } & \multicolumn{5}{|c|}{ Cut dates and intervals (month-day-year) } \\
\hline & $\begin{array}{l}01-14-14 \\
\text { (41 days) }\end{array}$ & $\begin{array}{l}\text { 02-19-14 } \\
\text { (35 days) }\end{array}$ & $\begin{array}{l}\text { 05-05-14 } \\
\text { (74 days) }\end{array}$ & $\begin{array}{l}\text { 07-19-14 } \\
\text { (64 days) }\end{array}$ & $\begin{array}{l}\text { 10-08-14 } \\
\text { (93 days) }\end{array}$ \\
\hline I & $11.56 \mathrm{abA}$ & $15.45 \mathrm{aA}$ & $15.31 \mathrm{abA}$ & $15.37 \mathrm{aA}$ & $12.86 \mathrm{abcB}$ \\
\hline II & 9.92 bA & $14.88 \mathrm{aA}$ & $15.36 \mathrm{abA}$ & $14.77 \mathrm{aA}$ & $12.54 \mathrm{abcB}$ \\
\hline III & $10.98 \mathrm{abAB}$ & $15.59 \mathrm{aAB}$ & $15.38 \mathrm{abAB}$ & $16.29 \mathrm{aA}$ & $13.66 \mathrm{abcB}$ \\
\hline IV & $12.10 \mathrm{abAB}$ & $16.04 \mathrm{aA}$ & $16.52 \mathrm{abA}$ & $16.29 \mathrm{aAB}$ & $14.37 \mathrm{abB}$ \\
\hline $\mathrm{V}$ & $10.36 \mathrm{abA}$ & $16.52 \mathrm{aA}$ & $16.26 \mathrm{abA}$ & $15.33 \mathrm{aAB}$ & $13.56 \mathrm{abcB}$ \\
\hline VI & $10.06 \mathrm{bA}$ & $15.10 \mathrm{aA}$ & $15.99 \mathrm{abA}$ & $15.66 \mathrm{aA}$ & $14.80 \mathrm{aA}$ \\
\hline VII & $11.82 \mathrm{abAB}$ & $14.96 \mathrm{aA}$ & $16.48 \mathrm{abA}$ & $15.82 \mathrm{aA}$ & $13.81 \mathrm{abcB}$ \\
\hline VIII & $10.41 \mathrm{abA}$ & $15.68 \mathrm{aA}$ & $14.66 \mathrm{abA}$ & $15.80 \mathrm{aA}$ & $12.16 \mathrm{bcB}$ \\
\hline IX & $11.39 \mathrm{abA}$ & $15.92 \mathrm{aA}$ & $15.65 \mathrm{abA}$ & $15.22 \mathrm{aA}$ & $14.04 \mathrm{abcA}$ \\
\hline $\mathrm{X}$ & $10.68 \mathrm{abA}$ & $14.68 \mathrm{aA}$ & $16.09 \mathrm{abA}$ & $15.89 \mathrm{aA}$ & $11.90 \mathrm{cB}$ \\
\hline Mar. & $11.54 \mathrm{abA}$ & $14.34 \mathrm{aA}$ & $14.29 \mathrm{bA}$ & $14.00 \mathrm{aA}$ & $13.68 \mathrm{abcA}$ \\
\hline Ken. & $12.49 \mathrm{aA}$ & $16.47 \mathrm{aA}$ & $6.74 \mathrm{aA}$ & $15.68 \mathrm{aA}$ & $13.61 \mathrm{abcB}$ \\
\hline
\end{tabular}

* Means followed by the same letter, uppercase and lowercase in the column, do not differ from each other by the Tukey test at $5 \%$ probability. Marandu = B. brizantha cv. Marandu; Kennedy $=$ B. ruziziensis cv. Kennedy. 
Table 5

Means of the Acid detergent fiber (\%) in percentages obtained in the improved populations and controls evaluated in five cuts in the municipality of Coronel Pacheco, MG

\begin{tabular}{|c|c|c|c|c|c|}
\hline \multirow[b]{2}{*}{ Pop. } & \multicolumn{5}{|c|}{ Cut dates and intervals (month-day-year) } \\
\hline & $\begin{array}{l}01-14-14 \\
\text { (41 days) }\end{array}$ & $\begin{array}{l}\text { 02-19-14 } \\
\text { (35 days) }\end{array}$ & $\begin{array}{l}05-05-14 \\
\text { (74 days) }\end{array}$ & $\begin{array}{l}07-19-14 \\
\text { (64 days) }\end{array}$ & $\begin{array}{l}10-08-14 \\
\text { (93 days) }\end{array}$ \\
\hline I & $38.40 \mathrm{abA}$ & $28.88 \mathrm{bcB}$ & $32.18 \mathrm{aB}$ & $29.13 \mathrm{abB}$ & $31.10 \mathrm{abB}$ \\
\hline II & $38.89 \mathrm{abA}$ & $29.16 \mathrm{bcC}$ & $33.33 \mathrm{aB}$ & $29.35 \mathrm{abC}$ & $27.86 \mathrm{abcdC}$ \\
\hline III & $39.93 \mathrm{abA}$ & $29.41 \mathrm{abcC}$ & $34.84 \mathrm{aB}$ & $27.38 \mathrm{bC}$ & $27.17 \mathrm{abcdC}$ \\
\hline IV & $38.90 \mathrm{abA}$ & $28.67 \mathrm{bcC}$ & $32.51 \mathrm{aB}$ & $28.00 \mathrm{bC}$ & $25.19 \mathrm{dC}$ \\
\hline $\mathrm{V}$ & $40.01 \mathrm{abA}$ & $27.77 \quad \mathrm{cC}$ & $32.51 \mathrm{aB}$ & $27.12 \mathrm{bC}$ & $26.68 \mathrm{bcdC}$ \\
\hline VI & $42.05 \mathrm{aA}$ & $29.89 \mathrm{abcBC}$ & $33.29 \mathrm{aB}$ & $27.66 \mathrm{bC}$ & $26.16 \mathrm{cdC}$ \\
\hline VII & $38.44 \mathrm{abA}$ & $28.66 \mathrm{bcC}$ & $33.48 \mathrm{aB}$ & $27.64 \mathrm{bC}$ & $26.94 \mathrm{abcdC}$ \\
\hline VIII & $39.36 \mathrm{abA}$ & $28.87 \mathrm{bcC}$ & $33.89 \mathrm{aB}$ & $28.51 \mathrm{bC}$ & $29.63 \mathrm{abcdC}$ \\
\hline IX & $38.16 \mathrm{abA}$ & $28.06 \mathrm{cC}$ & $33.23 \mathrm{aB}$ & $28.12 \mathrm{bC}$ & $28.67 \mathrm{abcdC}$ \\
\hline $\mathrm{X}$ & $39.56 \mathrm{abA}$ & $32.91 \mathrm{abB}$ & $31.94 \mathrm{aBC}$ & $28.68 \mathrm{bC}$ & $30.49 \mathrm{abcC}$ \\
\hline Mar. & $40.23 \mathrm{abA}$ & $33.89 \mathrm{aB}$ & $34.83 \mathrm{aB}$ & $33.68 \mathrm{aB}$ & $31.42 \mathrm{aB}$ \\
\hline Ken. & $37.06 \mathrm{bA}$ & $27.82 \mathrm{cC}$ & $32.40 \mathrm{aB}$ & $28.14 \mathrm{bC}$ & $25.88 \quad \mathrm{dC}$ \\
\hline
\end{tabular}

* Means followed by the same letter, uppercase and lowercase in the column, do not differ from each other by the Tukey test at $5 \%$ probability. Marandu = B. brizantha $\mathrm{cv}$. Marandu; Kennedy = B. ruziziensis cv. Kennedy.

In the joint analysis of the NDF means, population IV had the lowest NDF content in the cut intervals of 41 and 93 days. The lowest NDF levels were obtained in populations I to IX and in the Kennedy cultivar in the cut interval of 35 days, and III to X and in the Kennedy cultivar in the cut interval of 64 days. However, a difference between the means in the NDF levels between the populations and the controls was not observed in the 74-day interval (Table 6). The cuts performed at the 64 and 93 day intervals resulted in lower NDF levels. In evaluating Brachiaria brizantha Stapf. cv. Marandu, Gerdes, Werner, Colozza, Possenti and Schammass (2000) obtained $72.70 \%$ content with a cut interval of 35 days in the summer, and $78.14 \%$ in the Panicum maximum Jacq. cv. Tanzania ${ }^{-1}$ with the same cut interval and in the same season, all of which were higher than those found in the present study. These mean NDF values were close to the limit proposed by Van Soest (1965), which considers levels above $55-60 \%$ of cell wall constituents as limiting forage consumption. These populations showed high NDF digestibility, providing a high potential of DM consumption and a good production of milk and meat when used in grazing (Nussio, Campos, Paziani, \& Santos, 2002). 
Table 6

Mean values of neutral detergent fiber (NDF) in percentage obtained in the improved populations and controls in five cuts in the municipality of Coronel Pacheco, MG

\begin{tabular}{cccccc}
\hline & \multicolumn{5}{c}{ Cut dates and intervals (month-day-year) } \\
\cline { 2 - 6 } Pop. & $01-14-14$ & $02-19-14$ & $05-05-14$ & $07-19-14$ & $10-08-14$ \\
& $(41$ days $)$ & $(35$ days $)$ & $(74$ days $)$ & $(64$ days $)$ & (93 days) \\
\hline I & $65.44 \mathrm{abA}$ & $62.88 \mathrm{bA}$ & $64.61 \mathrm{aA}$ & $62.01 \mathrm{aA}$ & $62.96 \mathrm{abA}$ \\
II & $66.14 \mathrm{abA}$ & $63.40 \mathrm{bAB}$ & $65.29 \mathrm{aA}$ & $61.70 \mathrm{aB}$ & $60.57 \mathrm{abcB}$ \\
III & $64.99 \mathrm{abAB}$ & $62.57 \mathrm{bBC}$ & $67.21 \mathrm{aA}$ & $60.43 \mathrm{bC}$ & $62.74 \mathrm{abBC}$ \\
IV & $62.44 \mathrm{bAB}$ & $61.63 \mathrm{bAB}$ & $63.44 \mathrm{aA}$ & $59.77 \mathrm{bBC}$ & $57.99 \mathrm{cC}$ \\
V & $64.46 \mathrm{abA}$ & $61.26 \mathrm{bAB}$ & $64.10 \mathrm{aA}$ & $59.80 \mathrm{bB}$ & $58.98 \mathrm{bcB}$ \\
VI & $66.83 \mathrm{aA}$ & $63.45 \mathrm{bA}$ & $65.09 \mathrm{aA}$ & $59.57 \mathrm{bB}$ & $59.19 \mathrm{bcB}$ \\
VII & $65.17 \mathrm{abA}$ & $63.22 \mathrm{bAB}$ & $63.29 \mathrm{aAB}$ & $59.47 \mathrm{bC}$ & $60.16 \mathrm{abcBC}$ \\
VIII & $65.09 \mathrm{abAB}$ & $62.61 \mathrm{bABC}$ & $65.98 \mathrm{aA}$ & $60.79 \mathrm{bC}$ & $61.96 \mathrm{abcBC}$ \\
IX & $63.82 \mathrm{abAB}$ & $61.92 \mathrm{bABC}$ & $65.29 \mathrm{aA}$ & $59.55 \mathrm{bC}$ & $60.94 \mathrm{abcBC}$ \\
X & $64.27 \mathrm{abA}$ & $64.11 \mathrm{abA}$ & $63.45 \mathrm{aAB}$ & $60.35 \mathrm{bB}$ & $62.02 \mathrm{abcAB}$ \\
Mar. & $66.10 \mathrm{abAB}$ & $67.95 \mathrm{aA}$ & $66.67 \mathrm{aAB}$ & $66.32 \mathrm{aAB}$ & $63.72 \mathrm{aB}$ \\
\hline Ken. & $63.61 \mathrm{abA}$ & $61.81 \mathrm{bAB}$ & $63.92 \mathrm{aA}$ & $60.55 \mathrm{bAB}$ & $59.43 \mathrm{bcB}$ \\
\hline
\end{tabular}

* Means followed by the same letter, uppercase and lowercase in the column, do not differ from each other by the Tukey test at $5 \%$ probability. Marandu $=$ B. brizantha $\mathrm{cv}$. Marandu; Kennedy $=$ B. ruziziensis cv. Kennedy.

The plant age influences the chemical composition of forages, as occurred in the cut interval of 64 days (Carvalho \& Pires, 2008). Solar radiation and temperature exert great influence on the growth and productivity of a species (Atroch et al., 2001). There was a gradual increase in solar radiation and temperature in the period between the 64-day interval and the 93-day interval, which may explain the lower NDF content found in this cut interval (Figures 1 and 2).

The best CP, ADF and NDF levels observed in the populations IV (lower ADF and NDF levels at 93 days of cut interval, and lower NDF levels at 35 and 41-day intervals), population VI (higher CP content in the 93-day cut interval and lower NDF levels at 35 and 64-day cut intervals) confirm the statement by Serrão and Simão (1971) that Brachiaria ruziziensis is palatable even at an advanced maturation stage and that these populations can be evaluated under grazing.

\section{Conclusion}

The improved Brachiaria ruziziensis (Syn. Urochloa) populations generally obtained better performance than the Marandu cultivar and similar performance to the Kennedy cultivar. The improved populations IV and VI were selected for implanting experiments of grazing evaluations due to presenting the best nutritional values in the performed cuts in both the rainy season and in the dry season.

\section{Acknowledgements}

The authors acknowledge the Coordenação de Aperfeiçoamento de Pessoal de Nivel Superior (CAPES) for the awarded grants, the Conselho Nacional de Desenvolvimento Cientifico $e$ Tecnológico $(C N P q)$ and the Fundação de Amparo à Pesquisa do Estado de Minas Gerais (FAPEMIG) for partially financing the study. 


\section{References}

Atroch, E. M. A. C., Soares, A. M., Alvarenga, A. A., \& Castro, E. M. (2001). Crescimento, teor de clorofilas, distribuição de biomassa e características anatômicas de plantas jovens de Bauhinia forticata submetidas a diferentes condições de sombreamento. Ciência e Agrotecnologia, 25(4), 853-62.

Carvalho, G. G. P., \& Pires, A. J. V. (2008). Organização dos tecidos de plantas forrageiras e suas implicações para os ruminantes. Archivos de Zootecnia, 57(R), 13-28.

Cedeno, J. A. G., Rocha, G. P., Pinto, J. C., Muniz, J. A., \& Gomide, E. M. (2003). Efeito da idade de corte na performance de três forrageiras do gênero Cynodon. Ciência e Agrotecnologia, 27(2), 462-70. doi: 10.1590/S1413-70542003000200029

Costa, K. A. P., Oliveira, I. P., Faquin, V., Neves, B. P., Rodrigues, C., \& Sampaio, F. M. T. (2007). Intervalo de corte na produção de massa seca e composição químico-bromatológica da Brachiaria brizantha $\mathrm{cv}$. MG-5. Ciência e Agrotecnologia, 31(4), 1197-1202. doi:10.1590/S1413-70542007000400037

Ferreira, R. de P., Botrel, M. de A., Pereira, A. V., \& Cruz, C. D. (1999). Avaliação de cultivares de alfafa e estimativas de repetibilidade de caracteres forrageiros. Pesquisa Agropecuária Brasileira, 34(6), 995-1002. doi:10.1590/S0100-204X1999000600010

Flores, R. A., Urquiaga, S., Alves, B. J. R., Collier, L. S., Zanetti, J. B., \& Prado, R. de M. (2013). Nitrogênio e idade de corte na qualidade da biomassa de capimelefante para fins agroenergéticos cultivado em Latossolo. Semina: Ciências Agrárias, 34(1), 127136. doi: 10.5433/1679-0359.2013v34n1p127

Gerdes, L., Werner, J. C., Colozza, M. T., Possenti, R. A., \& Schammass, E. A. (2000). Avaliação de características de valor nutritivo das gramíneas forrageiras marandu, setária e tanzânia nas estações do ano. Revista Brasileira de Zootecnia, 29(4), 955963. doi: 10.1590/S1516-35982000000400003

Hallauer, A. R., Carena, M. J., \& Miranda, J. B. (2010). Genética quantitativa na produção de milho. Iowa: Iowa State University Press.

Lédo, F. J. da S., Pereira, A. V., Souza, F., Sob ${ }^{\circ}$, Auad, A. M., Jank, L., \& Oliveira, J. S. E. (2008). Estimativa de repetibilidade para caracteres forrageiros em Panicum maximum. Ciência e Agrotecnologia, 32(4), 1299 -1303. doi: 10.1590/S1413-70542008000400040

Leng, R. A. (1990). Factors affecting the utilization of "poor-quality" forages by ruminants particularly under tropical conditions. Nutrition Research Review, 3(3), 277-303. doi: 10.1079/NRR19900016

Leonel, F. P., Pereira, J. C., Costa, M. G., Marco, P., Jr., Silva, C. J., \& Lara, L. A. (2009a). Consórcio capimbraquiária e milho: comportamento produtivo das culturas e características nutricionais e qualitativas das silagens. Revista Brasileira de Zootecnia, 38(1), 166-176. doi: 10.1590/S1516-35982009000100021

Leonel, F. P., Pereira, J. C., Costa, M. G., Marco, P., Jr., Silva, C. J., Lara, L. A, \& Queiroz, A. C. (2009b). Comportamento produtivo e características nutricionais do capim-braquiária cultivado em consórcio com milho. Revista Brasileira de Zootecnia, 38(1), 177-189. doi: 10.1590/S151635982009000100022

Michael, T. P., Mockler, T. C., Breton, G., Mcentee, C., Byer, A., Trout, J. D.,... Chory, J. (2008). Network pipeli discovery ne elucidates conserved time-ofdayspecific cis-regulatory modules. Plos Genetic, 41(4). doi: 10.1371/journal.pgen.0040014

Minson, D. J. (1990). Forage in ruminant nutrition. London: Academic Press.

Norton, B. W. (1982). Differences between species in forrage quality. nutritional limits to animal production from pastures. Wallingford: Farnham Royal, Commonwealth Agricultural Bureaux. doi: $10.1177 / 003072708301200413$

Nussio, L. G., Campos, F. P., Paziani, S. F., \& Santos, F. A. P. (2002). Volumosos suplementares: estratégias de decisão e utilização. Anais do Simpósio sobre Forragicultura e Pastagens. Temas em evidência, Lavras, MG, Brasil, VIII, Lavras: UFLA.

Nussio, L. G., Manzano, R. P., \& Pedreira, C. G. S. (1998). Valor alimentício em plantas do gênero Cynodon. Anais do Simpósio sobre manejo de pastagem. Piracicaba: FEALQ/ESALQ.

Santos, P. M., Primavesi, O. M., \& Bernardi, A. C. de C. (2010). Adubação de pastagens. In A. V. Pires. (Ed.). Anais do Simpósio Bovinocultura de corte (pp. 459471). Piracicaba: FEALQ.

Santos, M. E. R., Fonseca, D. M., Braz, T. G. D., Silva, S. P., Gomes, V. M., \& Silva, G. P. (2011). Características morfogênicas e estruturais de perfilhos de capimbraquiária em locais do pasto com alturas variáveis. Revista Brasileira de Zootecnia, 40(3), 535-542. doi:10.1590/S1516-35982011000300010

Serrão, E. A., \& Simão, M., Neto. (1971). Informações sobre duas espécies de gramíneas forrageiras do gênero Brachiaria na Amazônia: Brachiaria 
decumbes. Stapf e Brachiaria ruziziensis Germain Everaed. Boletim do Instituto de Pesquisa Experimental Agropecuária do Norte, 1(1), 1-31.

Shimoya, A., Pereira, A. V., Ferreira, R. de P., Cruz, C. D., \& Carneiro, P. C. S. (2002). Repetibilidade de características forrageiras do capim-elefante. Scientia Agricola, 59(2), 227-234. doi:10.1590/ S0103-90162002000200004

Souza, F. de Sob ${ }^{\circ}$, Lédo, F. J. da S., Pereira, A. V., Botrel, M. A., Evangelista, A. R., \& Viana, M. C. M. (2004). Estimativas de repetibilidade para produção de matéria seca em alfafa. Ciência Rural. 34(2), 531537. doi: 10.1590/S0103-84782004000200030

Souza, F. de Sob , Lédo, F. J. S., Koop, M. M., Pereira, A. V., \& Souza, F. F. (2009). Melhoramento de gramineas forrageiras na VII Simpósio de forragicultura e pastagem. Lavras: Embrapa Gado de Leite.
Tilley, J. M. A., \& Terry, R. A. (1963). A two stage technique for the in vitro digestion of forage crops. Journal of the British and Grasslands Society, 18(1), 104-111. doi: 10.1111/j.1365-2494.1963.tb00335.x

Valle, C. B., Macedo, M. C. M., Euclides, V. P. B., Jank, L., \& Resende, R. M. S. (2013). Gênero brachiaria plantas forrageiras. Viçosa: Editora UFV.

Van Soest, P. J. (1965). Symposium on factors influencing the voluntary intake of herbage by ruminants: voluntary intake relation to chemical composition and digestibility. Journal of Animal Science, 24(3), 834-844. doi: $10.2527 /$ jas $1965.243834 \mathrm{x}$ 
